\title{
HUBUNGAN KONFORMITAS TERHADAP KELOMPOK DENGAN KEDISIPLINAN SISWA DI SEKOLAH PADA SISWA KELAS II SMU YKM TANJUNGSARI SUMEDANG
}

\author{
Roros Widianingsih, Tati S. D \& Agus Abdul Rahman \\ Fakultas Psikologi UIN Sunan Gunung Djati Bandung
}

In adolescence, conformity aspect in a peer group was one of important aspect in their social life since adolescences need safety and acceptability feeling from their peer group much more than other age group. Teenagers have conformity for their peer group and tend to accept and follow rules and standards adopted by their peer group including changing perception, opinion, behaviors and their attitudes to become more "acceptable" by their friend in a group.

Many teenagers have strong bond with their friends and tend to behave inappropriately with rules and values in society. Indisciplinary behavior conducted at school showed a correlation with their peer group which can be seen from their "breaking rules" attitudes such as, smoking in the class, inapproapriate clothing, not doing their homework and

Research methods used in this research is a correlational model and using Marvin Shaw's group conformity scale and student's disciplinary scale from Ausubel. SPSS 11.5 were then used to test the validity and reliability of those two measurement methods. Spearman rank correlation technique dan were used to analyze data taken from 129 students of Grade II SMU YKM Tanjungsari. Statistical analysis conducted in this research was given the result of -0,673 whilst by using testing criterion with significany 5 percent would then concluded that the research hypothese is acceptable.

Brief conclusion from this research was given a result that there is a negative relations between conformity toward the peer group with indisciplinary behavior conducted by Grade II students at SMU YKM Tanjungsari.

Keywords: Conformity, Self Regulatory

\section{Pendahuluan}

Dalam kehidupan sehari-hari sering terdengar keluhan dari guru atau pendidik dalam membimbing siswa remaja misalnya tidak mau menuruti aturan yang berlaku di sekolah. Sikap ini seringkali dianggap sebagai akibat perkembangan remaja dan biasanya para pendidik melibatkan orangtua agar dapat bekerjasama dalam menangani masalah tersebut. Dari orangtua dapat ditelusuri timbulnya sikapsikap tidak sesuai aturan.
Kegiatan sekolah merupakan salah satu kegiatan yang banyak menyita waktu remaja selain di rumah. Di sekolah remaja menyesuaikan diri dengan aturan yang berlaku, baik peraturan sekolah, guru, maupun teman sebaya. Sekolah berperan bagi perkembangan kepribadian anak melalui aturan-aturan yang dibuat di antaranya, sekolah merupakan tempat anak menghabiskan waktu selain di rumah, sekolah memberi pengaruh pada anak secara dini seiring perkembangan konsep dirinya, sekolah 
memberi kesempatan pada siswa untuk meraih sukses, dan sekolah memberi kesempatan pertama pada anak untuk menilai dirinya dan kemampuannya secara realistik. Dengan demikian sekolah merupakan lembaga pendidikan formal yang secara sistematik melaksanakan program bimbingan, pengajaran, dan latihan agar siswa mampu mengembangkan potensinya baik aspek moral spiritual, intelektual, emosional, maupun sosial.

Untuk menjalankan fungsinya ini sekolah harus menentukan aturan yang harus diikuti oleh siswa. Dengan penerapan kedisiplinan diharapkan siswa memiliki sikap yang sesuai dengan aturan sekolah. Pengertian disiplin di sini merupakan standar atau norma dalam kontrol eksternal bagi individu dalam berinteraksi dengan lingkungan. Pada akhirnya kontrol eksternal tersebut akan terinternalisasikan dalam diri. Dengan demikian kedisiplinan adalah kecenderungan perilaku individu dalam mematuhi, menaati, dan melaksanakan disiplin yang diterapkan di lingkungan, dimana individu berada (Ausubel, 1973).

Diduga perilaku tidak disiplin muncul karena remaja harus menyesuaikan diri dengan kelompok. Remaja masuk ke dalam kelompok karena ingin dianggap hebat, merasa lebih berarti dan diakui kebenarannya. Mereka merasa tidak diakui oleh kelompok kalau tidak mengikuti aturan kelompok. Teman sebaya mempunyai arti penting bagi remaja karena dapat memberikan dukungan emosional dan simpati ketika menghadapi masalah di rumah atau di sekolah. Dengan teman sebaya, remaja merasa aman dan lebih leluasa berbagi rahasia rencana maupun masalah yang dihadapi. Selain itu teman sebaya juga dapat berperan sebagai pemberi jawaban atau pertanyaan-pertanyaan yang jawabannya tidak berhasil didapatkan dari orangtua atau guru.

Kedekatan remaja dengan teman sebaya sering menjadi kekhawatiran para orangtua atau guru. Mereka merasa takut kehilangan pengaruh pada anak mereka dan digantikan dengan pengaruh teman sebaya. Karena selain sumber informasi, teman sebaya seringkali menjadi acuan dalam berperilaku sehingga perilaku teman sebaya sering diikuti oleh remaja. Untuk memperoleh penerimaan atau pengakuan remaja dalam melakukan identifikasi dan melakukan perilaku yang sama dengan kelompok sebayanya yang disebut konformitas.

Dalam kehidupan sehari-hari yang terjadi pada remaja, bentuk konformitas remaja terhadap kelompok sebaya diantaranya dari cara berpakaian, cara berbicara, dan berperilaku sosial lainnya. Dengan demikian teman sebaya mempunyai peran penting bagi remaja. Remaja sering menempatkan teman sebaya dalam posisi prioritas apabila dibandingkan dengan orangtua atau guru dalam menyatakan kesetiaannya (Yusuf, 2002).

Dampak positif atau negatif dari konformitas terhadap sebaya ini salah satunya ditentuan oleh karakterisitk kelompok sebaya sendiri. Jika remaja berinteraksi dengan kelompok sebaya yang mendukung pencapaian prestasi akademik dan memberikan persetujuan sosial pada anggota kelompok yang mendapat nilai 
bagus maka konformitas terhadap kelompok tersebut akan memberikan pengaruh positif pada remaja. Sebaliknya jika interaksi dengan kelompok yang membenci kegiatan akademik di sekolah dan lebih senang mabuk-mabukan, melanggar aturan, maka konformitas terhadap kelompok tersebut akan memberikan pengaruh negatif pada remaja.

Namun tidak semua remaja yang berinteraksi dengan kelompok yang mempunyai tingkah laku negatif, akan terbawa pengaruh negatif tersebut. Walaupun ia berinteraksi dan berteman dekat dengan kelompok sebayanya tersebut, tetapi ia tidak mengikuti semua kebiasaan kelompoknya. Tetapi ada juga remaja yang sangat mudah mengikuti perilaku kelompoknya, dalam artian ia mengikuti semua norma, standar serta kebiasaan-kebiasaan yang ada di kelompok sebayanya. Biasanya remaja seperti ini sangat menjunjung tinggi kebersamaan, memiliki ikatan yang kuat dengan kelompok sebaya sehingga seringkali mereka tidak lagi membedakan apakah tingkah laku yang mereka ikuti tersebut baik bagi dirinya atau malah merugikan diri sendiri.

Berdasarkan uraian di atas, peneliti tertarik untuk meneliti hubungan konformitas terhadap kelompok dengan kedisiplinan siswa di sekolah pada siswa kelas II SMU YKM Tanjungsari.

\section{Manfaat dan Tujuan Penelitian}

Tujuan dari penelitian ini adalah untuk memperoleh data secara empirik untuk mengetahui keeratan hubungan konformitas terhadap kelompok dengan kedisiplinan siswa di sekolah pada siswa kelas II SMU YKM Tanjungsari.

Penelitian ini diharapkan dapat memberikan kegunaan teoretis dan praktis, antara lain:

1. Secara teoretis, yaitu untuk mengetahui hubungan konformitas terhadap kelompok sehingga remaja mampu berinteraksi dengan lingkungan secara adekuat dalam memahami peraturan yang ada dalam kelompok.

2. Secara praktis, hasil penelitian diharapkan dapat menjadi bahan masukan bagi orangtua, guru, dan sekolah dalam memahami perubahan perilaku remaja sehingga dapat membentuk remaja yang mampu berinteraksi dengan lingkungan dan tidak terbawa oleh pengaruh negatif dari kelompok sebaya.

\section{Kerangka Berpikir}

Remaja adalah satu periode dalam kehidupan manusia yang ditandai oleh berlangsungnya suatu proses peralihan dari masa anak-anak menuju dewasa. Masa remaja berlangsung sejak individu berusia 13 tahun sampai ia menginjak usia sekitar 18 tahun (Hurlock, 1980). Remaja merupakan suatu periode transisi dimana individu baik secara fisik maupun psikis, berubah dari seorang anak menjadi seorang dewasa. Lazimnya masa remaja dianggap sebagai masa yang telah matang secara seksual dan berakhir saat ia mencapai kematangan secara hukum.

Pada masa remaja terdapat perubahan perilaku dan sikap, yang sering terjadi pada 
masa remaja awal dibandingkan remaja akhir. Masa remaja awal berlangsung kira-kira usia 13 tahun sampai 16 atau 17 tahun. Sedangkan remaja akhir berlangsung antara usia 16 tahun atau 17 tahun sampai 18 tahun (Hurlock, 1980).

Remaja merupakan masa pencarian identitas. Berbagai pertanyaan yang berkaitan dengan dirinya akan muncul, seperti siapa saya, akan jadi apa saya kelak, apakah saya memang seperti apa yang saya pikirkan? Selama proses menemukan jawaban pertanyaan-pertanyaan tersebut tidak jarang remaja mengalami berbagai dilema dan kebingungan (Hurlock, 1980).

Remaja ingin mulai memberikan kesan bahwa mereka sudah hampir dewasa. Namun berpakaian dan bertindak seperti orang dewasa ternyata belumlah cukup. Karena itu remaja mulai memutuskan untuk berperilaku yang berhubungan dengan status dewasa yaitu merokok, meminum minuman keras, menggunakan obat-obatan terlarang, dan terlibat perbuatan seks. Mereka menganggap bahwa perilaku ini akan memberikan citra yang mereka inginkan (Hurlock, 1980).

Dalam perubahan sosial, ciri penting yang menandai masa remaja adalah terjadinya pergeseran atau perubahan arah orientasi sosial, dari orangtua kepada kelompok sebaya (peer group). Kelompok sebaya menjadi sesuatu yang penting karena mulai menggeser kedudukan keluarga sebagai sumber utama yang memberikan umpan balik bagi remaja, memberikan standar dalam bertingkah laku.

Manfaat yang dirasakan remaja dalam berhubungan dengan teman sebaya adalah:
1. Memberikan rasa aman. Melalui kelompok sebaya, remaja berkesempatan untuk menjalin persahabatan yang erat sehingga mem berikan rasa aman.

2. Memberikan hiburan yang menyenangkan. Keinginan remaja yang kuat untuk melepaskan diri dari pengaruh orangtua. Ketergantungan secara emosional pada orangtua menimbulkan keinginan untuk mandiri dan dapat menghabiskan waktu bersama dengan teman sebaya.

3. Memberikan pengalaman pergaulan yang cocok. Ketika berhubungan dengan kelompoknya, akan membuat remaja menyadari perbedaan yang dimiliki teman-temannya. Untuk itu remaja belajar bagaimana memahami orang lain dan menerima kekurangan dan kelebihan dirinya sehingga ia dapat belajar menyesuaikan diri dengan teman-temannya.

4. Mengembangkan sikap toleran.

5. Memperoleh dan mengembangkan keterampilan sosial. Misalnya sikap bagaimana menghormati orang lain, cara menegur agar tidak menyakiti orang lain.

6. Memberikan pola dan standar perilaku.

7. Kesempatan mencapai kemerdekaan pribadi dan keberartian kelompok. Ketika me masuki kelompok tertentu, remaja merasa memiliki otoritas orang dewasa, dapat berbuat apa saja asalkan sejalan dengan standar yang telah ditetapkan kelompok. Ini membuat remaja semakin diterima oleh kelompoknya. 
Ada beberapa tahap yang harus ditempuh dalam pembentukan kelompok sebaya (Nurihsan, 2003), yaitu:

1. Adanya kesadaran untuk berhubungan dengan orang lain. Kesadaran ini hanya sebatas informasi dan kesamaan serta penampilan fisik, misalnya wajah, postur tubuh, dan cara berpakaian.

2. Kontak permulaan. Hubungan antar remaja terjadi dalam frekuensi cukup tinggi misalnya bertemu di kantin, perpustakaan, atau tempat tertentu. Terjadi komunikasi walaupun belum intensif.

3. Saling berhubungan timbal balik. Hubungan remaja menjadi akrab melalui saling bertukar pengetahuan, pengalaman, perasaan, membantu satu sama lain. Pada tahap ini teman sebaya berubah menjadi sahabat.

Kelompok sosial yang sering terjadi selama masa remaja (Hurlock, 1999) yaitu:

1. Teman dekat (chums). Remaja biasanya mempunyai dua atau tiga teman dekat atau sahabat karib. Mereka adalah sesama jenis kelamin yang mempunyai minat sama. Teman dekat saling mempengaruhi walaupun kadang-kadang bertengkar.

2. Kelompok kecil (clique). Biasanya terdiri dari teman-teman dekat. Mulanya dari jenis kelamin sama kemudian meliputi dua jenis kelamin.

3. Kelompok besar (crowd) Terdiri dari beberapa kelompok kecil dan kelompok teman dekat. Biasanya berhubungan dalam aktivitas khusus.

4. Kelompok yang terorganisasi. Kelompok yang dibina oleh orang dewasa, dibentuk oleh sekolah atau masyarakat untuk memenuhi kebutuhan sosial.

5. Kelompok geng. Remaja yang tidak memasuki kelompok besar dan tidak puas dengan kelompok terorganisir, mungkin akan mengikuti kelompok geng. Anggotanya biasanya terdiri dari anak-anak sejenis dan minat utama mereka adalah untuk menghadapi penolakan teman-teman melalui perilaku anti sosial.

Konformitas didefinisikan sebagai kecenderungan mengubah persepsi menjadi sesuai norma kelompok (Shaw, 1977). Menurut Kartini Kartono dalam kamus psikologi (1987) definisi konformitas adalah kecenderungan untuk dipengaruhi oleh tekanan kelompok dan tidak menentang norma-norma yang telah digariskan oleh kelompok. Sedangkan menurut Henry (1994) konformitas adalah suatu perubahan dalam pendapat atau perilaku seseorang sebagai akibat dari pengaruh sosial. Terakhir menurut Yusuf (2002) konformitas adalah motif untuk menjadi sama, seragam dengan nilai-nilai, kebiasaan, kegemaran (hobi) atau budaya teman sebaya.

Tingkat konformitas terhadap suatu kelompok ditentukan oleh beberapa faktor, diantaranya yaitu:

1. Kohesivitas kelompok. Ini dapat dilihat dari daya tarik kelompok bagi individu dan tingkat identifikasi individu dalam kelompok. Semakin tinggi ketertarikan terhadap kelompok maka kohesivitas individu dalam kelompok akan tinggi.

2. Penguatan (reinforcement). Konformitas bervariasi sebagai fungsi dari imbalan dan 
hukuman. Pada waktu kelompok mengakui individu, individu sesuai dengan penilaian kelompok maka hal tersebut akan memberikan penguatan kepada individu untuk memilih 'sesuai' pada situasi tertentu.

Interaksi dalam kelompok memiliki pengaruh yang penting dalam perilaku konformitas. Konformitas akan meningkat jika kelompok yang mempengaruhi dapat memiliki karakteristik sebagai berikut (Shaw, 1997):

1. Terdiri dari tiga atau lebih. Suatu kelompok yang terdiri dari tiga orang anggota, cenderung lebih mudah muncul perilaku yang konformitas dibanding pada kelompok yang terdiri dari satu dua orang saja. Konformitas meningkat seiring dengan bertambah besarnya ukuran kelompok.

2. Kesepakatan (anonimous). Kelompok dengan anggota yang dikenal lebih mudah memunculkan perilaku konformitas daripada kelompok dengan anggota-anggota yang tidak dikenal.

3. Memberikan penguatan (reinforcement). Kelompok menyukai individu ketika ia sesuai dengan penilaian dan keyakinan kelompok.

4. Kohesif. Anggota dari kelompok yang kohesif secara teoretis akan conform terhadap norma kelompok dan memberikan respon positif terhadap pengaruh yang ditimbulkan kelompok.

Hurlock membagi derajat konformitas terhadap teman sebaya menjadi tiga tingkatan yaitu:

1. Developmentally appropriate conformity. Remaja dapat menerima dan mengikuti standar atau aturan-aturan yang ditetapkan oleh kelompok tanpa kehilangan identitas pribadinya.

2. Lack of conformity. Remaja tidak mampu menyesuaikan baik tingkah laku maupun pendapatnya dengan standar atau aturan yang ditetapkan kelompok. Konformitas pada tingkat ini sering mengakibatkan penolakan sosial dari kelompok.

3. Over conformity. Semua tingkah laku disesuaikan dengan standar atau aturanaturan yang ditetapkan kelompok, sehingga kehilangan identitasnya sebagai pribadi. Pengertian kedisiplinan dalam kehidupan sehari-hari adalah merupakan kecenderungan perilaku individu dalam mematuhi, menaati, dan melaksanakannya. Menurut Hurlock (1973) disiplin berasal dari bahasa Yunani 'disciplina' yang berarti mengajar atau memerintah. Secara etimologi, disiplin adalah mengajarkan seseorang untuk bertingkah laku sesuai dengan harapan masyarakat. Selanjutnya Hurlock (1973), mengatakan bahwa disiplin akan membantu seseorang dalam mengembangkan 'self control' dan 'self direction' sehingga ia dapat mengambil keputusan.

Dalam lingkungan sekolah, disiplin merupakan suatu peraturan yang telah ditetapkan terlebih dahulu. Dalam konteks ini kepala sekolah dan guru merupakan pemimpin yang menerapkan disiplin sedangkan siswa-siswa adalah penganut atau pengikut pada pola-pola, aturan-aturan yang ditetapkan sekolah. Peraturan tata tertib sekolah memiliki tujuan untuk menciptakan kondisi yang lebih baik guna mencapai dan memenuhi tujuan pendidikan. 


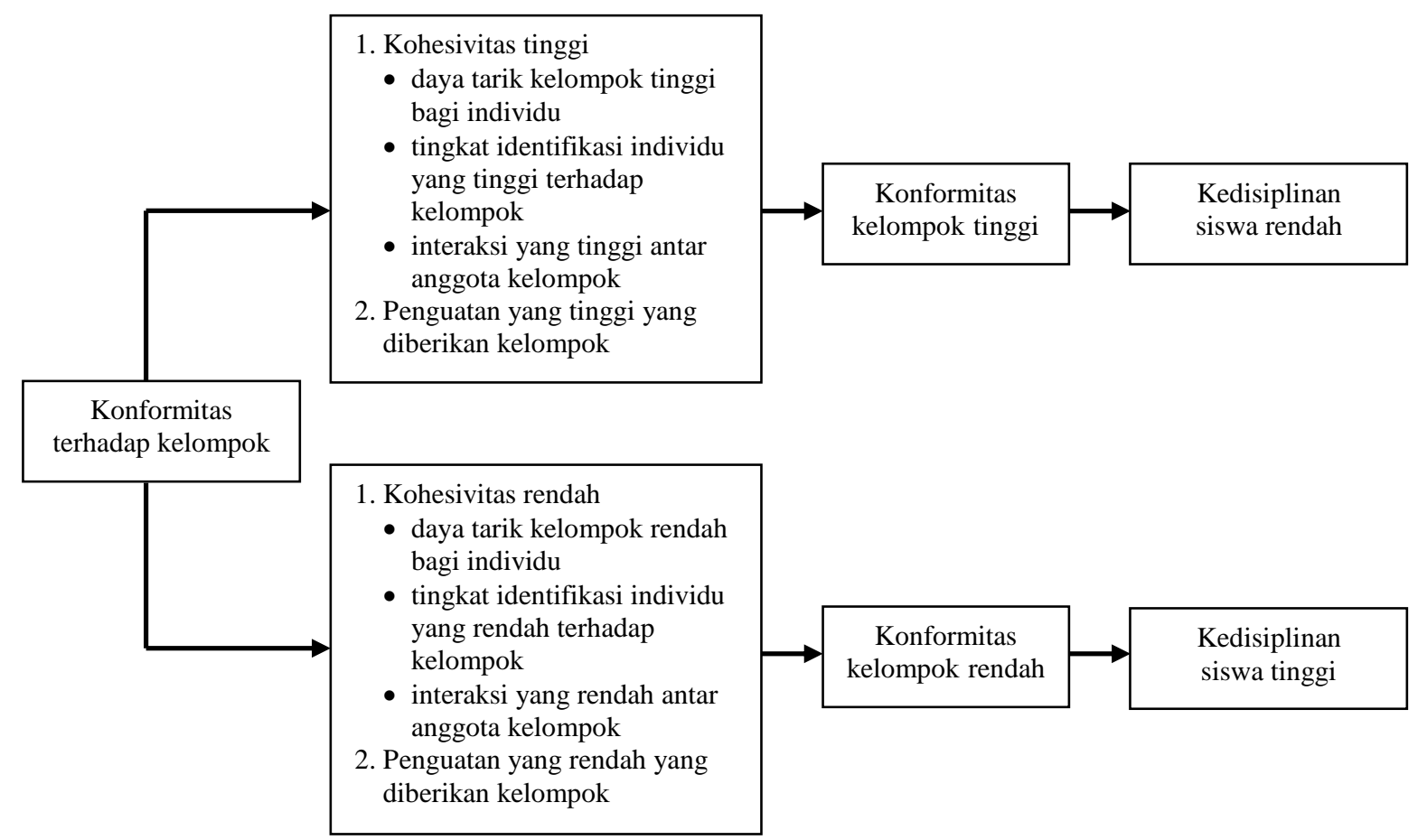

Gambar 1. Skema hubungan konformitas terhadap kelompok dengan kedisiplinan siswa

Disiplin negatif memperbesar ketidakmatangan individu, sedangkan disiplin positif akan membawa hasil yang lebih baik daripada negatif.

Berdasarkan uraian di atas, kerangka pemikiran dari penelitian ini dapat digambarkan dalam suatu skema seperti pada gambar 1 .

\section{Rumusan Permasalahan}

Proses pendidikan di sekolah merupakan suatu pencapaian tujuan yang dikehendaki, harus dilaksanakan secara efektif dan efisien. Kedudukan siswa sebagai subyek dan obyek dalam pendidikan, karena itu siswa harus menaati, mematuhi, dan melaksanakan semua peraturan yang telah ditetapkan sekolah. Dengan mengikuti semua peraturan, siswa diharapkan dapat diarahkan pola pikir, sikap, dan perilaku yang sesuai dengan peraturan sekolah. Terutama dalam kegiatan belajar mengajar, siswa hendaknya berperilaku disiplin. Misalnya datang ke sekolah tepat waktu, ketika proses belajar mengajar sedang berlangsung siswa menyimak dan memperhatikan setiap materi pelajaran yang disampaikan guru. Maupun setelah proses belajar itu selesai, siswa mengulang kembali pelajaran yang telah diberikan.

Ketidakdisiplinan siswa misalnya sering membolos pada jam pertama dan terakhir, merokok di kelas, berpakaian semaunya, tidak memakai tanda pengenal, serta perilaku tidak wajar seperti menentang guru, terlambat masuk sekolah, dan tidak mengerjakan tugas yang diberikan guru. Diduga ini terjadi karena mereka masuk ke dalam kelompok.

Dari uraian di atas maka permasalahan pokok yang ingin diteliti adalah bagaimana hubungan konformitas terhadap kelompok dengan kedisiplinan siswa di sekolah? 


\section{Metode Penelitian}

Metode penelitian yang digunakan adalah metode korelasional yaitu untuk menyelidiki keeratan hubungan antara variabel konformitas terhadap kelompok dengan kedisiplinan siswa di sekolah.

1. Subjek Penelitian

Karakteristik subjek yang diperlukan dalam penelitian ini adalah:

a. Remaja, yaitu usia 15-18 tahun

b. Pendidikan orangtua berkisar dari SD hingga perguruan tinggi

Penelitian ini merupakan jenis penelitian populasi karena dilakukan terhadap semua subyek dalam populasi yaitu siswa kelas II SMU YKM Tanjungsari yang berjumlah 129 orang.

\section{Alat Ukur}

Pengumpulan data dilakukan dengan alat ukur berupa skala. Terdapat dua macam skala yang digunakan, yaitu skala konformitas terhadap kelompok dan skala kedisiplinan siswa di sekolah. Selain menggunakan kedua skala ini juga dilakukan wawancara pada guru dan siswa untuk mendapatkan data tambahan mengenai kedisiplinan siswa di sekolah.

a. Skala konformitas terhadap kelompok

Skala ini dibuat berdasarkan teori Marvin Shaw (1977). Alat ukur ini disusun dengan model skala Likert menggunakan lima alternatif jawaban. Jumlah keseluruhan item adalah 40 item yang terdiri dari pernyatan positif (favorable) dan pernyataan negatif (unfavorable).

Pilihan jawaban pada skala ini berkisar antara Sangat Sesuai (SS), Sesuai (S), Kurang
Sesuai (KS), Tidak Sesuai (TS), dan Sangat Tidak Sesuai (STS). Skor diberikan dengan aturan berikut:

\begin{tabular}{|c|c|c|}
\hline $\begin{array}{c}\text { Alternatif } \\
\text { jawaban }\end{array}$ & $\begin{array}{c}\text { Nilai item } \\
\text { positif }\end{array}$ & $\begin{array}{c}\text { Nilai item } \\
\text { negatif }\end{array}$ \\
\hline SS & 5 & 1 \\
\hline S & 4 & 2 \\
\hline KS & 3 & 3 \\
\hline TS & 2 & 4 \\
\hline STS & 1 & 5 \\
\hline
\end{tabular}

Tabel 1. Nilai sikap konformitas terhadap kelompok

b. Skala kedisiplinan siswa di sekolah

Skala ini dibuat berdasarkan teori Ausubel (1973). Alat ukur ini juga disusun dengan model skala Likert menggunakan lima alternatif jawaban. Jumlah keseluruhan item adalah 40 item yang terdiri dari pernyatan positif (favorable) dan pernyataan negatif (unfavorable). Pilihan jawaban berkisar antara Sering Sekali (SS), Sering (S), Kadang-Kadang (KK), Pernah (P), dan Tidak Pernah (TP). Skor diberikan pada pernyataan positif adalah $\mathrm{SS}=5$, $\mathrm{S}=4, \mathrm{KK}=3, \mathrm{P}=2$, dan $\mathrm{TP}=1$. Sedang skor untuk pernyataan negatif adalah $\mathrm{SS}=1, \mathrm{~S}=2$, $\mathrm{KK}=3, \mathrm{P}=4$, dan $\mathrm{TP}=5$.

\section{Analisis Data}

a. Analisa item

Dalam penyusunan skala, sebelum melakukan analisa reliabilitas dan validitas, perlu dilakukan analisa item. Pengujian reliabilitas dan validitas hanya layak dilakukan pada kumpulan item yang telah teruji dan terpilih (Azwar, 2000:161). Analisa item dilakukan terhadap kedua variabel yaitu konformitas terhadap kelompok dan kedisiplinan siswa di sekolah dengan cara menghitung koefisien korelasi antara skor tiap item dengan 
skor secara keseluruhan yang dikenal dengan istilah korelasi item-total (item-total correlation $=\mathrm{r}_{\mathrm{ix}}$ ) Karena data berskala ukur ordinal maka digunakan formula Spearman's Rank-Order Correlation Coefficient (Siegel, 1986: 250-257), yaitu

$r_{s}=1-\frac{6 \sum_{i=1}^{N} d_{i}^{2}}{N^{3}-N}$

Jika proporsi angka sama pada kedua variabel besar, maka digunakan persamaan (2) yaitu:

$$
r_{s}=\frac{\sum x^{2}+\sum y^{2}-\sum d_{i}^{2}}{2 \sqrt{\sum x^{2} \sum y^{2}}}
$$

dimana:

$d_{i}$ : selisih antara dua ranking

$N$ : jumlah responden

$\sum x^{2}=\frac{N^{3}-N}{12}-\sum T_{x}$

$\sum y^{2}=\frac{N^{3}-N}{12}-\sum T_{y}$

dengan $T=\frac{t^{3}-t}{12}$

$x$ dan $y$ : variabel-variabel yang akan dikorelasikan

$\mathrm{t}$ : banyak observasi yang berangka sama

pada suatu ranking tertentu

Nilai $r_{s}$ yang diperoleh menunjukkan nilai daya beda item. Makin tinggi koefisien korelasi positif antara skor item dengan skor skala, berarti makin baik kesesuaian antara item dengan keseluruhan skala. Sebagai kriteria, umumnya item yang memiliki indeks daya beda lebih dari atau sama dengan $0,3 \quad\left(\mathrm{r}_{\mathrm{ix}} \geq 0,3\right)$ di-anggap memuaskan (Azwar, 2002). b. Uji Reliabilitas

Reliabilitas adalah indeks yang menunjukkan sejauhmana suatu alat ukur dapat dipercaya atau diandalkan (Ancok, 1995). Suatu alat ukur diaktakan reliabel jika dalam beberapa kali pelaksanaan pengukuran terhadap kelompok subyek yang sama, diperoleh hasil yang relatif sama, selama aspek dalam diri subyek belum berubah (Azwar, 1992). Dalam perhitungannya reliabilitas dinyatakan oleh koefisien reliabilitas $\left(\mathrm{r}_{\mathrm{xx}}\right)$ yang angkanya berada pada rentang $0-1$. Semakin mendekati 1 berarti semakin tinggi reliabilitas alat ukur.

Untuk menghitung koefisien reliabilitas dalam penelitian ini diguna-kan metoda Splithalf Spearman-Brown. Caranya yaitu nilai reliabilitas skala ditentukan dengan mencari indeks korelasi antara variabel jumlah skor tiap individu pada item-item ganjil dan variabel jumlah skor tiap individu pada item-item genap. Rumus Spearman-Brown Prophesy adalah sebagai berikut:

$$
r_{b}=\frac{(N)\left(r_{l}\right)}{1+(N-1)\left(r_{l}\right)}
$$

dimana

$N=2$

$r_{b}$ : indeks korelasi hasil koreksi

$r_{l}$ : indeks korelasi Rank-Spearman

c. Uji Validitas

Validitas adalah indeks yang menunjukkan sejauhmana suatu alat ukur dapat mengukur apa yang ingin diukur (Ancok, 1995). Dalam penelitian ini digunakan prosedur pengujian validitas konstruk dengan mencari indeks korelasi antara skor masing-masing faktor atau aspek skala dengan skor total skala. Karena skor total skala dan 
skor masing-masing faktor berskala ordinal, maka untuk menentukan indeks korelasi tersebut digunakan Rank-Order Correlation Coefficient dari Spearman. Adapun rumus dan langkahlangkahnya sama dengan analisa item, hanya saja berbeda dalam variabelnya.

Tidak ada batasan baku tentang angka minimal yang harus dipenuhi agar suatu skala dianggap valid. Kriteria umum yang digunakan adalah standar Guilford seperti berikut:

\begin{tabular}{|c|c|}
\hline $\begin{array}{c}\text { Interval } \\
\text { koefisien }\end{array}$ & Tingkat hubungan \\
\hline$<0,20$ & Tidak ada korelasi \\
\hline $0,20-0,40$ & Korelasi rendah \\
\hline $0,40-0,70$ & Korelasi sedang \\
\hline $0,70-0,90$ & Korelasi tinggi \\
\hline $0,90-1,00$ & Korelasi tinggi sekali \\
\hline 1,00 & Korelasi sempurna \\
\hline
\end{tabular}

Tabel 2. Kriteria koefisien reliabilitas Guilford

\section{Uji Statistik}

a. Hipotesis statistik

Untuk melakukan uji statistik terhadap hipotesis yang telah diajukan, maka diturunkan hipotesis statistik sebagai berikut:

$H_{0}: r_{s} \geq 0$

Tidak terdapat hubungan yang negatif antara konformitas terhadap kelompok dengan kedisiplinan siswa di sekolah.

$H_{1}: r_{s}<0$

Terdapat hubungan negatif antara konformitas terhadap kelompok dengan kedisiplinan siswa di sekolah

b. Analisa uji korelasi

Telah dijelaskan bahwa peneliti menggunakan correlational research method. Karena data berskala ukur ordinal maka digunakan sta- tistik uji Rank Spearman. Formulasi dan langkahlangkah perhitungannya sama seperti yang sudah dijelaskan pada bagian analisa item. Sedangkan uji signifikansi untuk menerima atau menolak $H_{0}$ dilakukan dengan uji student seperti berikut: $t=r_{s} \sqrt{\frac{n-2}{1-r_{s}^{2}}}$

Kriteria uji untuk penolakan $H_{0}$ adalah

$t_{\text {hitung }} \geq t_{\text {tabel }}$

Atau jika perhitungan dilakukan dengan bantuan SPSS maka kriteria ujinya adalah:

$p_{\text {value }} \leq \alpha$

Untuk mengetahui besarnya kontribusi variabel konformitas terhadap kelompok dengan kedisiplinan siswa di sekolah maka dihitung nilai koefisien determinasi dengan formulasi berikut:

$d=r_{s}^{2} \times 100 \%$

\section{Hasil Penelitian}

\section{Statistik Deskriptif}

Perhitungan deskriptif diawali dengan aturan pengelompokkan skor total setiap variabel untuk setiap kategori.

Hasil kategorisasi konformitas terhadap kelompok dan kedisiplinan siswa di sekolah dapat dilihat pada tabel 3 dan tabel 4.

\begin{tabular}{|c|c|c|}
\hline Konformitas & Jumlah & $\%$ \\
\hline Tinggi & 54 orang & 43 \\
\hline Sedang & 61 orang & 49 \\
\hline Rendah & 9 orang & 7 \\
\hline
\end{tabular}

Tabel 3. Kategori konformitas terhadap kelompok Sumber: Hasil Pengolahan Data Penelitian

Dengan rincian sebagai berikut: 


\begin{tabular}{|c|c|c|c|}
\hline Konformitas & Kedisiplinan & Jumlah & $\%$ \\
\hline \multirow{3}{*}{ Tinggi } & Tinggi & 5 orang & 4 \\
\cline { 2 - 4 } & Sedang & 29 orang & 23 \\
\cline { 2 - 4 } & Rendah & 20 orang & 16 \\
\hline \multirow{3}{*}{ Sedang } & Tinggi & 25 orang & 20 \\
\cline { 2 - 4 } & Sedang & 32 orang & 25 \\
\cline { 2 - 4 } & Rendah & 4 orang & 3 \\
\hline \multirow{3}{*}{ Rendah } & Tinggi & 9 orang & 7 \\
\cline { 2 - 4 } & Sedang & - & - \\
\cline { 2 - 4 } & Rendah & - & - \\
\hline
\end{tabular}

Tabel 4. Rincian kategorisasi konformitas terhadap kelompok

Sumber: Hasil Pengolahan Data Penelitian

\section{Analisa Uji Korelasi}

Dari hasil perhitungan statistik diperoleh koefisien korelasi antara konformitas terhadap kelompok dengan kedisiplinan siswa di sekolah sebesar -0,673. Hasil lengkapnya dapat dilihat pada tabel 5. Dengan taraf signifikansi $\alpha=0,05$ maka berdasarkan kriteria pengujian $p_{\text {value }} \leq \alpha$ diputuskan untuk menolak $H_{0}$ dan menerima $H_{1}$. Artinya terdapat hubungan negatif yang signifikan antara konformitas dengan kedisiplinan siswa di sekolah pada siswa kelas II SMU YKM Tanjungsari.

\begin{tabular}{|c|c|c|c|}
\hline Variabel & $\mathrm{N}$ & $r_{s}$ & $p_{v}$ \\
\hline $\begin{array}{c}\text { Konformitas terhadap } \\
\text { kelompok dengan } \\
\text { Kedisiplinan siswa }\end{array}$ & 124 & $-0,673$ & 0,00 \\
\hline
\end{tabular}

Tabel 5. Korelasi Konformitas dengan kedisiplinan siswa di sekolah

Sumber: Hasil Pengolahan Data Penelitian

\section{Simpulan dan Saran}

1. Simpulan

Dari analisa hasil penelitian tentang hubungan konformitas terhadap kelompok de- ngan kedisiplinan siswa di sekolah dapat ditarik beberapa kesimpulan, yaitu:

a. Hipotesis penelitian diterima. Artinya, terdapat hubungan negatif yang signifikan antara konformitas terhadap kelompok dengan kedisiplinan siswa di sekolah. Artinya semakin tinggi konformitas terhadap kelompok maka semakin rendah kedisiplinan siswa di sekolah.

b. Hasil kategorisasi pada variabel konformitas diperoleh konformitas yang bervariasi pada individu. Individu akan memperoleh penguatan untuk memilih 'sesuai' pada situasi tertentu jika ia sesuai dengan penilaian dan keyakinan kelompok. Penguatan ini ditentukan oleh kohesivitas kelompoknya.

2. Saran

Beberapa saran yang berkaitan dengan hasil penelitian adalah sebagai berikut:

a. Bagi sekolah

Penerapan disiplin merupakan salah satu faktor penting untuk mencapai tujuan pendidikan yang optimal. Kedisiplinan dapat meningkatkan ketaatan siswa terhadap peraturan sekolah. Kedisiplinan tidak hanya dilaksanakan oleh siswa saja, tetapi juga dilaksanakan oleh guru atau semua pihak yang terkait dalam sekolah.

b. Bagi guru BP

Berikanlah bimbingan dan arahan yang baik pada siswa individu atau kelompok yang memiliki kedisiplinan rendah agar dapat memahami aturan sekolah dan menyesuaikan sikap dan perilakunya. 
c. Bagi siswa

Interaksi merupakan bagian dari pengalaman remaja dimana mereka harus mengikuti aturan dan norma yang ditetapkan teman sebayanya. Dengan interaksi sesama, remaja lebih bisa memahami dirinya. Tetapi remaja harus lebih berhati-hati dengan pengaruh yang diberikan kelompok sebayanya. Interaksi ini dapat memberikan pengaruh positif yang mendukung pencapaian prestasi dan memberikan persetujuan sosial bagi diri remaja. Selain itu juga dapat memberi pengaruh negatif.

d. Bagi penelitian selanjutnya

Disadari bahwa hasil penelitian ini belum optimal, terutama dalam menyusun instrumen penelitian untuk mengukur pemahaman siswa. Diharapkan ada penelitian lanjut tentang aspek-aspek yang belum diungkap dalam penelitian ini.

\section{Daftar Pustaka}

Ahmad, Abu. (1992). Psikologi Umum Bina Ilmu. Jakarta: Rineka Cipta

Ahmad, Abu. (1995). Psikologi Sosial. Jakarta: Rineka Cipta

Ali, Lukman. (1995). Kamus Besar Bahasa Indnesia. Jakarta: Depdik-bud

Ancok, Djamaludin. (1989). Teknik Penyusunan Skala: Pengantar. Yogyakarta: Pusat Penelitian Kependidikan Universitas Gajah Mada

Ausubel. (1973). Educational Psychology.

Azwar, Saepudin. (1999). Penyusunan Skala Psikologi. Edisi 1. Yogya-karta: Pustaka Pelajar.

Chaplin. (2001). Kamus Lengkap Psikologi. Jakarta: Raja Grafindo Persada.

Henry. (1994). Kamus Psikologi. Bandung: Armico
Hurlock, EB. (1999). Psikologi Perkembangan. Suatu pendekatan sepanjang rentang kehidupan. Edisi 5. Jakarta: PT Erlangga.

Nasrulloh, Ade. (2002). Kontribusi Kualitas Interaksi Sosial Kelompok Teman Sebaya di Sekolah terhadap Kreativitas Siswa. Bandung: IKIP

Kartono, Kartini. (1987). Kamus Psikologi. Bandung: Pionir Jaya

Mappiare, Andi. (1982). Psikologi Remaja. Jakarta: PT Gramedia.

Pryodarminto, Soegeng. (1992). Disiplin Kiat Menuju Sukses. Jakarta: PT Pradirja Paramitra

Schaefer, Charles. (1991). Bagaimana Mempengaruhi Perkembangan Anak. Semarang: Daharaprize

Siegel, Sidney. (1986). Statistik Nonparametrik untuk Ilmu-ilmu Sosial. Terjemahan Zanzawi Suyuti \& Landung Simatupang. Jakarta: Gramedia Pustaka.

Subari. (1994). Suverpisi Pendidikan dalam Rangka Perbaikan Situasi Mengajar. Jakarta; Bumi Aksara.

Sugiy0ono. (2003). Statistik untuk Penelitian. Bandung: CV Alfabeta

Sudjana, N. (1996). Metode Statistika. Edisi 5. Bandung: PT Tarsito.

Suharsimi, A. (1993). Dasar-dasar Evaluasi Pendidikan Bandung: Bumi Aksara.

Suharsimi, A. (1995). Prosedur Penelitian. Bandung: Rineka Cipta.

Sujanto, Agus. (1996). Psikologi Perkembangan. Jakarta: Rineka Cipta.

Shaw, Marvin (1971). Group Dinamics. New Delhi : Company

Surya, M. (1999). Psikologi Perkembangan. Bandung: PPB, FIP IKIP

Yusuf, Syamsu. (2002). Psikologi Perkembangan Anak dan Dewasa. Bandung: PT Rosda Karya

Winkel, WS. (1996). Psikologi Pengajaran. Jakarta: PT Gramedia 
